\title{
DINASTI FATIMIYAH : ANALISIS KEMAJUAN DAN RUNTUHNYA PERADABAN ISLAM DI MESIR
}

\section{Irwan Supriadin J}

STIT Sunan Giri Bima - NTB

Email: irwansupriadin@gmail.com

\begin{tabular}{|c|c|c|c|}
\hline Received : & Submit : & Edited : & Published : \\
\hline 02 Januari 2021 & "07 Januari 2021 & 09 Januari 2021 & 19 Januari 2021 \\
\hline
\end{tabular}

\begin{abstract}
This article intends to present an analysis of the progress and decline of the Fatimid dynasty, and their impact on Islamic civilization in Egypt. This caliphate was born between two political powers, the Abbasids in Baghdad, and the Umayyad II in Cordova. Over a period of 262 years, the Fatimids have made rapid progress, especially during the time of Al-Muiz, Al-Aziz and Al-hakim. These advances cover various fields, namely: 1) Progress in trade relations with the non-Islamic world, including India and the Christian Mediterranean countries. 2) Advances in art, can be seen in a number of palace decorations and architecture. 3) In the field of knowledge with the construction of Al-Azhar University. 4) In the economic sector, both in the agricultural, trade and industrial sectors. 5) In the field of security. The collapse of the Fatimid dynasty was caused by several weaknesses that existed during his reign. These weaknesses include: 1) Fatimid politics which is harsh on the Egyptian Sunni community to adhere to and recognize Shi'a teachings. 2) The control over the Fatimid territories was weakened, 3) the economy of the people and the state was weak, 4) There was resistance from the Sunnis and Christians in Egypt. 5) The struggle for power between the Barbarians and the Turks, especially in the military field. 6) The invasion of the crusaders. And the role of the caliphate is not fully functional.
\end{abstract}

Keyword: Fatimid dynasty, progress, destruction, Islamic civilization

\begin{abstract}
ABSTRAK
Artikel ini bermaksud mengemukakan analisis kemajuan dan kemunduran dinasti fatimiyah, serta dampaknya terhadap peradaban Islam di Mesir. Kekhalifahan ini lahir diantara dua kekuatan politik, Abbasiyah di Baghdad, dan Umayah II di Cordova. Selama kurun waktu 262 tahun, Fatimiyah telah mencapai kemajuan yang pesat terutama pada masa Al-Muiz, Al-Aziz dan Al-hakim. Kemajuan-kemajuan itu mencakup berbagai bidang, yaitu: 1) Kemajuan dalam hubungan perdagangan dengan Dunia non Islam, termasuk India dan negeri-negeri Mediteramia yang Kristen. 2) Kemajuan di bidang seni, dapat dilihat pada sejumlah dekorasi dan arsitektur istana. 3) Dalam bidang pengetahuan dengan dibangunnya Universitas Al-Azhar. 4) Di bidang ekonomi, baik sektor pertanian, perdagangan maupun industri. 5) Di bidang keamanan. Keruntuhan Dinasti Fatimiyah disebabkan oleh beberapa kelemahan yang ada pada masa pemerintahannya. Kelemahan-kelemahan itu antara lain: 1) Politik Fatimiyah yang keras terhadap masyarakat sunni Mesir untuk menganut dan mengakui ajaran Syi'ah. 2) Pengawasan terhadap daerah-daerah kekuasaan Fatimiyah melemah, 3) Lemahnya perekonomian rakyat dan negara, 4) Adanya resistensi dari orang-orang Sunni dan Nasrani di Mesir. 5) Terjadinya perebutan kekuasaan antara bangsa Barbar dan bangsa Turki terutama dalam bidang militer. 6) Datangnya serbuan dari tentara salib. Dan peran khilafah tidak berfungsi secara utuh.
\end{abstract}

Kata Kunci: Dinasti Fatimiyah, Kemajuan, Kehancuran, Peradaban Islam 


\section{PENDAHULUAN}

Sejarah jika ditunjau dari segi bahasanya, sejarah berasal dari bahasa Arab “syajaratun", artinya pohon. Apabila digambarkan secara sistematik, sejarah hampir sama dengan pohon, memiliki cabang dan ranting, bermula dari sebuah bibit, kemudian tumbuh dan berkembang, lalu layu dan tumbang. Seirama dengan kata sejarah adalah silsilah, kisah, hikayat yang berasal dari bahasa Arab. ${ }^{1}$ Dalam sejarah dijelaskan bahwa setelah masa kekuasaan khulafā al-Rāsyidin, dunia Islam mulai dipimpin oleh para penguasa yang membentuk kekuasaan dengan system kekeluargaan atau dinasti. Salah satunya dinasti Umayyah yang didirikan oleh Muawiyah, dalam dinasti ini system pemerintahannya bersifat monarchi hereditis (kerajaan turun temurun).

Kekuasaan Muawiyah diperoleh melalui kekerasan dan diplamasi, tidak dengan pemilihan atau suara terbanyak. System kepemimpinan terlihat ketika Muawiyah mewajibkan seluruh rakyatnya untuk menyatakan setia terhadap anaknya Yazid yang kelak menggantikannya. Banyak dinasti-dinasti yang berkuasa setelah khulafā al-Rāsyidin, di antaranya: Dinasti Umayyah, Dinasti Abasiyyah, Dinasti Umayyah di Andalusia, Dinasti Safawiyah, Dinasti Usmani di Turki, Dinasti Mongol Islam di India, dan beberapa dinasti lain yang berkuasa di beberapa belahan dunia Islam. Selain dinasti-dinasti yang disebutkan di atas, juga terdapat beberapa dinasti lain yang juga memilki peran penting dalam pengembangan di dunia Islam, salah satunya yang menjadi pembahasan ini, yaitu Dinasti Fatimiyah.

\section{Sejarah Berdirinya Dinasti Fatimiyah}

Dinasti Fatimiyah adalah satu-satunya Dinasti Syi'ah dalam Islam. Dinasti ini didirikan di Tunisia pada 909 M., sebagai tandingan bagi penguasa dunia muslim saat itu yang terpusat di Baghdad, yaitu Bani Abbasiyah. ${ }^{2}$ Di dalam Ensiklopedi disebutkan bahwa seruan untuk membentuk Dinasti Fatimiyah berhasil karena dilakukan dengan sistem perencanaan dan pengaturan yang baik. Para dai yang bertugas menyebarluaskan seruan tersebut berhasil menjadikan wilayah Maroko sebagai negeri syi'aih, mendeklarasikan berdirinya dinasti Fatimiyah untuk pertama kalianya di daerah Raqqādah pada tanggal 21 rabiu al-sāni $297 \mathrm{H}(15$ Januari $910 \mathrm{M}){ }^{3}$

\footnotetext{
${ }^{1}$ William H. Frederick dan Soeri Soeroto, Pemahaman Sejarah Indonesia, sebelum dan sesudah revolusi (Jakarta; LP3ES, 1982), h.1.

${ }^{2}$ Philip K. Hitti, History Of The Arabs (Jakarta: Serambi Ilmu Semesta, 2010), h.787.

${ }^{3}$ Abdul Mun'im al-Hafni, Ensiklopedi Golongan, Kelompok, Aliran, Mazhab, Partai, dan Gerakan Islam Seluruh Dunia, Juz I (Cet. II; Jakarta: PT. Grafindo Khazanah Ilmu, 2009), h.469.
} 
Dinasti ini mengklaim sebagai keturunan garis lurus dari pasangan Ali bin Ab Thalib dan Fatimah binti Rasulullah saw. Menurut mereka, Abu Abdullah al-Mahdi merupakan cucu Ismail bin Ja'far al-Shadiq, sedangkan Ismail merupakan keturunan Syiah yang ketujuh. Setelah Imam Ja'far al-Shadiq wafat, Syi'ah terpecah menjadi dua cabang. Cabang pertama meyakini Musa al-Kazim sebagai Imam ketujuh pengganti Imam Ja'far, sedang sebuah cabang lainnya mempercayai Ismail bin Muhammad al-Maktum imam Syi'ah ketujuh. Cabang syi'ah kedua ini dinamai Syi'ah Ismailiyah. ${ }^{4}$

Dinasti Fatimiyah didirikan oleh Sa'id bin Husain, kemungkinan keturunan pendiri sekte Ismailiyah, seorang Persia yang bernama 'Abdullah bin Maymūn. ${ }^{5}$ dalam sejarah peraban Islam dijelaskan bahwa Abdullah bin Maymūn adalah orang yang membentuk Syi'ah Ismailiyah sebagai sebuah system gerakan politik keagaman. ${ }^{6}$ Kemunculan Sa'id, penerus Ibn Maymūn yang sangat mencengangkan ini merupakan puncak dari propaganda sekte Ismailiyah yang terampil dan teroganisir dengan baik. Kesuksesan mereka itu sama dengan kesuksesan pertama sekte ini, yang pernah berhasil menggoyang kekhalifahan Umayyah. Keberhasilan gerakan ini tidak bisa dilepaskan dari upaya personal dai (propogandis) utama sekte ini, yaitu Abū Abdullah al-Husayn al-Syi'ì. ia adalah seorang penduduk asli Shan'à Yaman, yang menjelang awal abad ke-9 memproklamirkan dirinya sebagai pelopor Mahdi, dan menyebarkan hasutan di tengah suku Berber di Afrika Utara, khususnya suku Kitamah. Perkenalannya dengan anggota suku ini terjadi pada musim haji di Mekkah. Wilayah Afrika kecil-Tunisia dan Afrika Utara ketika itu berada di bawah kekuasaan Aghlabiyah.

Sukses gemilang yang diraih oleh al-Syi'ì di wilayah asing mendorong Sa'ìd untuk meninggalkan wilayah Ismailiyah di Salamiyah, dan pergi sambil menyamar sebagai pedagang menuju barat laut Afrika. Ketika ia terlempar di penjara Sijilmasah atas perintah penguasa Dinasti Aghlabiyah, Ziyādatullah (903-909), Said ditolong oleh al-Syi’ì, yang kemudian pada 909 menghancurkan Dinasti Aglabiyah yang telah berkuasa selama beberapa abad, dan mengusir keturunan terakhir Ziyādatullāh keluar dari negeri itu. Dinasti Aglabiyah merupakan kubu terakhir kekuatan Islam-Sunni di wilayah Afrika. Sa'ìd memproklamirkan dirinya sebagai penguasa dengan julukan imam Ubaydullāh al-Mahdi dan mengklaim sebagai keturunan Fatimah melalui al-Husain dan Isma'íl. Dinasti yang didirikannya sering disebut sebagai Dinasti al-Ubaydiyah, khususnya oleh mereka yang tidak mempercayainya sebagai keturunan Fatimah. ${ }^{7}$

\footnotetext{
${ }^{4}$ Samsul Munir Amin, Sejarah Peradaban Islam (Jakarta: Amzah, 2010), h. 254.

${ }^{5}$ Philip K. Hitti, History Of The Arabs., h. 787.

${ }^{6}$ Samsul Munir Amin, Sejarah Peradaban Islam ., h.255.

${ }^{7}$ Samsul Munir Amin, Sejarah Peradaban Islam ., h.788.
} 
Menurut Prof Azumardi Azra, berdirinya Dinasti Fatimiyah dilatar belakangi oleh Dinasti Abbasiyah. Kemudian Ubaidullāh al-Mahdi mendirikan Dinasti Fatimiyah yang lepas dari kekuasaan Abbasiyah. ${ }^{8}$ disebutkan pula bahwa pada mulanya orang Syi'ah bekerja sama dengan Bani Abbasiyah untuk menggulingkan Bani Umaiyyah, namun stelah Bani Abbas mendapat kemenangan, ternyata mereka memonopoli kekuasaan, sehingga orang-orang Syi'ah mengadakan gerakan-gerakan perlawanan terhadap Bani Abbas, antara lain Qarāmițah, Hasyāsīn dan lain-lain, akhirnya terbentuklah dinasti Fatimiyah di Tunisia, ${ }^{9}$ dengan ibu kotanya Qairawan, Afrika Utara. ${ }^{10}$

\section{Kepemimpinan Al-Mahdi}

Al-Mahdi merupakan penguasa Fatimiyah yang cakap. Dua tahun semenjak penobatannya, ia menghukum pimpinan propogandanya yakni Abu Abdullah al-Husain karena terbukti bersekongkol dengan saudaranya yang bernama abul Abbas untuk melancarkan perebutan jabatan khalifah. Kemudian al-Mahdi melancarkan gerakan perluasan wilayah kekuasaan ke seleruh Afrika yang terbentang dari Mesir sampai dengan wilayah Fes di Maroko. Pada tahun 914 M, ia menduduki Alexandria. Kota-kota lainnya seperti, Malta, Syria, Sardinia, Corsica, dan sejumlah kota lain jatuh dalam kekuasaannya. ${ }^{11}$ Pada tahun $920 \mathrm{H}$, khalifah al-mahdi mendirikan kota baru di pantai Tunisia dan menjadikannya sebagai Ibu Kota Fatimiyah. Kota ini dinamakan kota Mahdiniyah. AlMahdi ingin menaklukan Spanyol dari kekuasaan Umayyah. Oleh karena itu, ia menerima hubungan persahabatan dan kerja sama dengan Muhammad bin Hafsun, pimpinan pergerakan pemberontakan di Spanyol. Namun ambisinya ini belum berhasil sampai ia meninggal dunia pada tahun $934 \mathrm{M}$.

\section{Kepemimpinan Al-Qa'im}

Al-Mahdi digantikan oleh putranya yang tertua yang bernama Abul Qasim dan bergelar al-Qaim. Ia meneruskan gerakan ekspansi yang telah dimulai oleh ayahnya. Pada tahun 934 M, ia mengarahkan pasukan dalam jumlah besar ke daerah selatan pantai Prancis. Pasukan ini berhasil menduduki wilayah sepanjang pantai Calibria. Pada saat yang sama ia juga melancarkan pasukannya ke Mesir, namun pasukan ini berhasil dikalahkan oleh Dinasti Ihsidiyah sehingga mereka terusir dari Alexandria.

${ }^{8}$ Azumardi Azra, (Pimpinan Redaksi), Ensklopedi Islam (Jakrata; Ikhtiar Baru Van Hoove, 2005), h.

${ }^{9}$ Yusran Asmuni, Dirāsah Islāmiyah II Pengantar Studi Sejarah Kebudayaan Islam dan Pemikiran (Cet. III; Jakarta: Raja Grafindo Persada, 1998), h.13.

${ }^{10}$ H. Soekama Karya dan Tim Penyusun, Ensiklopedi Mini Sejarah dan Kebudayaan Islam (Cet. I; Jakarta: Logos Wacana Ilmu, 1996), h.350.

${ }^{11}$ Hasan Ibrahim Hasan, Sejarah dan Kebudayaan Islam (Yogyakarta: Kota Kembang, 1989), h. 229. 
Al-Qaim merupakan prajurit pemberani, dan beliau merupakan kahlifah Fatimiyah pertama yang menguasai lautan tengah. Al-Qaim meninggal pada tahun $946 \mathrm{M}$, ketika itu sedang terjadi pemberontakan di Susa' yang dipimpin oleh Abu Yazid. Al-Qaim digantikan oleh putranya yang bernama al-Manshur. Al-Manshur berhasil menghancurkan kekuatan Abu Yazid dan akhirnya seluruh wilayah di Afrika tunduk pada Dinasti Fatimiyah. ${ }^{12}$

\section{Kepemimpinan Mu'iz li Dīnillah}

Ketika al-Manshur meninggal, putranya yang bernama Abu Tamim Ma'ad yang bergelar al-Mu'iz li Dīnillah bin Mansur bin al-Qāim bin al-Mahdi Ubaidillah menggantikan kedudukan ayahnya sebagai khalifah pada hari Ahad, tujuh Żulhijjah $341 \mathrm{H}^{13}$ Penobatan Mu'iz sebagai khalifah ke empat menandai era baru Dinasti Fatimiyah. Banyak keberhasilah yang dicapainya, di antaranya: 1) Menciptakan keadilan dan kemakmuran, 2) Membasmi pemberontak secara tuntas, 3) Memperhatikan program ekspansi kekuasaan, 4) Penaklukan atas Maroko, 5) Penaklukan atas wilayah Sicilia, 6) Mendirikan sebuah universitas keodokteran di kota Palemo Sicilia, 7) Penaklukan Mesir kota Fustat (Kairo) dan berakhirnya Dinasti Ikhsidiyah, 8) Mendirikan mesjid al-Azhar yang kemudian oleh khalifah al-Aziz sebagai pendidikan tinggi al-Azhar ${ }^{14}$

Khalifah al-Muiz meninggal pada tahun $975 \mathrm{M}$, setelah memerintah selama 23 tahun. Ia merupakan khalifah yang terbesar. Ia pendiri Dinasti Fatimyah di Mesir. Kecakapannya sebagai negarawan terbukti oleh perubahan Fatimiyah sebagai Dinasti kecil menjadi imperium besar. ${ }^{15}$ Dan tujuannya menciptakan kemakmuran dan keadilan, hal ini terlihat ketika beliau memasuki Mesir, beliau berkata bahwa kedatanganku ke Mesir bukan untuk memperluas wilayah atau menambah kekayaan, melainkan untuk menegakkan kebenaran, menjaga jama'ah haji, menyatakan jihad melawan orang-orang kafir, mengakhiri hidup dengan beramal saleh dan menunaikan apa yang diprintahkan oleh nenek moyangnya yakni Nabi Muhammad saw., hal ini pula yang membuat para hadirin meneteskan karena mendengar ucapan beliau. Kemudian Setibanya di Kairo, ia langsung bersujud dan shalat dua rakaat. ${ }^{16}$

\section{Kepemimpinan Al-Aziz}

Khalifah Abu Manshur Nizar al-Aziz, menggantikan kedudukan ayahnya Mu'iz. Pada masa kekhalifahannya merupakan puncak kejayaan Dinasti Fatimiyah. Wilayahnya sudah meliputi Syiria, Hijaz, Yaman dan Wilayah dari Atlantik dan Laut Merah.

\footnotetext{
${ }^{12}$ Samsul Munir Amin, Sejarah Peradaban Islam, h.257.

${ }^{13}$ Abu al-Abbās Syamsuddin Ahmad bin Muhammad bin Abi Bakr bin Khalkān, Wafayāt al-A 'yān wa
} Anbāu AbnāI al-Zamān, Juz V (Cet. I; Beirut: Dār al-Ṣādir, 1994), h.224-225.

\footnotetext{
${ }^{14}$ K. Ali, Sejarah Islam (Tarikh Pramodern) (Jakarta: Srigunting, 1997 ), h. 330.

${ }^{15}$ Samsul Munir Amin, Sejarah Peradaban Islam, h.259.

${ }^{16}$ Abi Bakr bin Khalkān, Wafayāt al-A 'yān wa Anbāu AbnāI al-Zamān., h.227.
} 
Pembangunan berjalan dengan baik, jembatan, jalan-jalan, irigasi, bangunan-bangunan masjid, dan tempat-tempat umum menunjukan prestasi yang gemilang. Bahkan beliau juga menorehkan hidup damai dan saling menghormati dengan kalangan Kristen Kopti. ${ }^{17}$

Pada era Aziz ini, muncul beberap ilmuan di antaranya adalah Ibnu Yunus, penemu pendulum dan ukuran waktu dengan ayunannya. Kegiatan ilmiah dilanjutkan oleh Ibn alNabdi dan al-haitham. Dalam sejarah al-Haitham dikenal sebaai penemu teori bahwa cahaya datang ke mata dari obyek, bukan dari mata mnju obyek. al-Haitham merupakan seorang astronom dan ahli optika. ${ }^{18}$ Pembangunan fisik dan seni arsitektur merupakan lambang kemajuan pada masa ini. Bangunan megah banyak didirikan di kota Kairo seperti The Golden Palace, The pear pavilion, dan Mesjid Karava. Dia adalah seorang penyair dan tokoh pendidikan. Pada masa beliau diresmikanlah sebagai lembaga pendidikan. Al-azis pada tahun 996 Masehi dan bersamaan dengan ini, berakhirlah kejayaan Dinasti fathimiyah. ${ }^{19}$

\section{Kepemimpinan Al-Hakim}

Sepeninggal Al-Aziz, khalifah Fathimiyah dijabat oleh anaknya bernama Abu AlMansur Al-Hakim. Ketika naik tahta ia berusia sebelas tahun. Selama tahun-tahun pertama Al-Hakim berada di bawah pengaruh seorang gubernurnya yang bernama Barjawan. Barjawan terlibat konflik dengan panglima militer Ibnu Ammar. Setelah berhasil menyingkirkan panglima, Barjawan menjadi pelaku utama pemerintahan Al-Hakim. Di kemudian hari Al-Hakim mengambil tindakan menghukum bunuh terhadap Barjwan lantaran penyalahgunaan kekuasaan negara.

Pemerintahan Al-Hakim ditandai dengan sejumlah kekejaman. Ia menhukum mati pejabat-pejabat yang cakap tanpa alasan yang jelas. Dalam sepuluh tahun masa pemerintahnnya, kaum Yahudi dan Nasrai merasa kehilangan hak-haknya sebagai warga negara sehigga mereka pun melakukan perlawanan. Al-hakim segera mengeluarkan maklumat umum untuk menghancurkan seluruh greja Kristen di Mesir dan menyita tanah dan harta kekayaan mereka. Ibnu Abdun, seorang menteri sekretariat negara yang beragama Kristen dipaksa menandatangani maklumat tersebut. Kalangan Kristen dipaksa memilih tiga alternatif, yaitu menjadi muslim, atau meninggalkan tanah air, atau berkalung dengan salib raksasa sebagai symbol kehancuran mereka. ${ }^{20}$

Al-hakim adalah pribadi muslim yang taat. Ia pendiri sebuah tempat pmujaa suku aliran Druz di Lebanon, yang smpai sekarang masih ada. Al-Hakim mendirikan sebuah

\footnotetext{
2011), h.92.

${ }^{18}$ Phil K. Hitty, Capital Cities Of Arab Islam (Minneapolis : University Of Minnesota, 1973), h.114.

${ }^{19}$ Samsul Munir Amin, Sejarah Peradaban Islam., h.259.

${ }^{20}$ K. Ali, Sejarah Islam (Tarikh Pramodern), h.334.
}

${ }^{17}$ Syamsul Bakri, S.Ag., M.Ag., Peta Sejarah Peradaban Islam (Cet. I; Yokyakarta: fajar Media Press, 
mesjid, perguruan, dan pusat observatori di Syiria. Di antara mesjid yang dibangunnya terdapat sebuah mesjid yang menjadi lambang kemajuan arsitektur yang indah. Pada tahun 1306 M, ia menyelesaikan pembangunan Dar Al-Hikmah (gedung pusat ilmu pengetahuan) sebagi saran penyebaran teologi Syi'ah, sekaligus untuk kemajuan kegiatan pengajaran.

Dar Al-Hikmah dilengkapi dengan sebuah perpustakaan besar dan berada di dekat istan kerajaan. Gedung ini terbuka untuk umum. Tamu negara selalu menyempatkan diri mengunjugi gedung ini. Di tempat inilah para penulis dan pemikir berkumpul. Masa pemerintahan al-Hakim berjalan selama 25 tahun dan salah satunya jasanya yang besar sebagaimana dijelaskan di atas yaitu mendirikan Dar al-Hikmah. ${ }^{21}$

\section{Kepemimpinan Az-Zahir}

Al-Hakim digantikan oleh putranya yang bernama Abu-Hasyim Ali dengan gelar AzZahir. Ia naik tahta pada usia enam belas tahun, sehingga pusat kekuasan dipegang oleh bibinya yangbernama Sitt Al-Mulk. Sepeninggal bibinya, Az-Zahir menjadi raja boneka di tangan menterinya. Pada masa pemerintahan ini rakyat menderita kekurangan bahan makanan dan harga barang tidak dapat terjangkau. Kondisi ini disebabkan terjadinya musibah banjir terus-menerus.

Peristiwa yang paling terkenang pada masa ini adalah penyelesaian persegketaan keagamaan pada tahun 1025 di mana tokoh-tokoh mazhab Malikiyah diusir dari Mesir. Sekalipun demikian, secara umum Az-Zahir cukup toleran terhadap kelompok Sunni. Ia bersedia membuat perjanjian dengan Kaisar Romawi, yakni Kaisar Costantine VIII. Sang Kaisar diizinkan membangun kembali gereja Yerussalem yang roboh akibat kerusuhan yang terjadi disana. Ia meninggal pada $1036 \mathrm{M}$, setelah memerintah selama 16 tahun. $^{22}$

\section{Kepemimpinan Al-Mustansir}

Az-Zahir digantikan oleh anaknya yang bernma Abu Tamim Ma'ad yang bergelar Mustansir., pemerintahnya selama 61 tahun yang merupakan masa pemerintahan terpanjang dalam sejarah islam. ${ }^{23}$ Masa awal pemerintahannya berada sepenuhnya di tangan ibunya, namun ketika dinobatkan sebagai khaifah ia berusia tujuh tahun. Pada masa ini Dinasti Fathimiyah mengalami kemunduran yang sangat drastis. Beberapa kali perebutan jabatan perdana menteri turut memperlemah ketahanan imperium ini, di samping terjadinya sejumlah pemberontakan dan peperangan selama pemrintahan ini.

Raja muda Zarida di Afrika yang bernama Muiz melemparkan penghinaan kepada Dinasti Fathimiyah dengan tidak menyebut nama Khalifah Fathimiyah dalam khutbah

\footnotetext{
${ }^{21}$ H. Zaenal Abidin Ahmad, Sejarah Islam dan Ummatnya(Jakarta: Bulan bintang, 1979), h.109.

${ }^{22}$ Samsul Munir Amin, Sejarah Peradaban Islam, h.261.

${ }^{23}$ Hasan Ibrahim Hasan, Sejarah dan Kebudayaan Islam., h.243-244.
} 
Jum'atnya, melainkan menggantikan dengan menyebut nama Khalifah Abbasiyah. ${ }^{24}$ Namun, Al-Mustansir tidak tertarik untuk memerangi Muiz bin Badis di Afrika. Sang khalifah lebih tertarik dengan pemberontakan Al-Bassiri terhadap pemerintahan Abbasiyah, dan menjadikannya sebagai kesempatan untuk menegakkan kembali kekuasaannya di Asia Barat serta Turghil menegakkan kekuasaan Abbasiyah di wilayah ini.

Pada masa khalifah ini pula mesir dilanda permusuhan antara militer negeri dan militer Turki. Mileter Turki dengan panglima Nasir berhasil menduduki kota Kairo pada tahun 1068 M. akibat ini Mesir dilanda wabah penyakit, kesuliatan pangan dan garis-garis kalangan atas terpaksa menjual perhiasan untuk membelikan makanan. Kemudian khalifah Al-Mustansir meminta bantuan gubernur Aceh yang bernama Badar Al-Jamal sehingga musibah ini dapat teratasi. ${ }^{25}$

\section{Kepemimpinan Al-Musta'li}

Merupakan putra termuda al-Mustansir yang menduduki tahta setelah meninggalnya ayahnya. Dan Nizar putra tertua menentang penobatan adiknya. Ia segera bangkit di Alexandria setelah memecat gubernur wilayah ini, namun setahun kemudian ia dapat dipaksa menyerah. Dan sepeninggalnya al-Musta'li, anaknya yag masih muda al-Amir Manshur dinobatkan sebagai khalifah oleh al-Afzal karena beliau merupakan perdana menteri yang absolute selama 20 tahun masa pemerintahan al-Amir. Berkat beliau juga Mesir menjadi cukup damai dan makmur. ${ }^{26}$

Setalah al-Amir meninggal karena dibunuh yang diakibatkan karena politik, kemenakannya al-Hafiz memproklamirkan diri sebagai khalifah. Pemerintahan al-Hafiz ini diwaranai dengan perpecahan antar unsure kemiliteran. Dan sepeninggalnya, anaknya Abu Mansur Ismail al-Zafir yang menggantikan beliau dan usianya 17 tahun, al-Zafir tidak peduli dengan urusan politik pemerintahan. Kemudian anak al-Zafir yang masih kecil yang menggantikan ayahnya yang digelari al-Faiz. Ia meninggal dunia sebelum dewasa dan digantikan kemenakannya al-Azid. Sewaktu naik tahta, sang khalifah berusia Sembilan tahun. Ia merupakan khalifah Dinasti Fatimiyah yang ke empat belas dan mengakhiri masa pemerintahan Fatimiyah selama lebih kurang dua setengah abad. Sultan Salahuddin alAyyubi menurunkan al-Azid dari khalifah Fatimiyah terakhir ini pada tahun 1171 M. ${ }^{27}$

\footnotetext{
${ }^{24}$ Merupakan kebiasaan pada masa itu, seorang khatib dalam bagian akhir khutbah Jum'atnya menyebut nama khalifah sebagai tanda penghormatan dan pengakuannya.

${ }^{25}$ Samsul Munir Amin, Sejarah Peradaban Islam., h.263.

${ }^{26}$ Samsul Munir Amin, Sejarah Peradaban Islam., h.263.

${ }^{27}$ K. Ali, Sejarah Islam (Tarikh Pramodern), h.338.
} 


\section{Kemajuan Peradaban Pada Masa Dinasti Fatimiyah}

\section{Bidang Administrasi}

Periode Dinasti Fatimiyah menandai era baru sejarah bangsa Mesir. Sebagian khalifah dinasti ini adalah pejuang dan penguasa besar yang berhasil menciptakan kesejahteraan dan kemakmuran di Mesir. Administrasi kepemerintahan Dinasti Fatimiyah secara garis besar tidak berbeda dengan administrasi Dinasti Abbasiyah, sekalipun pada masa ini muncul beberapa jabatan yang berbeda. Khalifah menjabat sebagai kepala negara baik dalam urusan keduniaan maupun spiritual. Khalifah berwenang mengangkat dan sekaligus menghentikan jabatan-jabatan di bawahnya.

Kementrian negara (wazir) terbagi menjadi dua kelompok; pertama adalah para ahli pedang dan kedua adalah para ahli pena. Kelompok pertama menduduki urusan militer dan keamanan serta pengawal pribadi sang khalifah. Sedang kelompok kedua menduduki beberapa jabatan kementerian, di antaranya: hakim, pejabat pendidikan sekaligus pengelola lembaga pengetahuan atau Där al-Hikmah, Inspektur pasar yang bertugas menertibkan pasar dan jalan, pejabat keuangan yang sekaligus menangani keuangan negara, regu pembantu istana, petugas pembaca al-Qur'an. Tingkat terendah pegawai "ahli pena" terdiri atas kelompok pegawai negeri, yaitu petugas penjaga dan juru tulis dalam berbagai departemen. ${ }^{28}$ Adapun di luar jabatan istana di atas, terdapat berbagai jabatan tingkat daerah yang meliputi tiga daerah, yaitu: Mesir, Syiria, dan empat provinsi, provinsi Mesir bagian atas, Mesir wilayah timur, Mesir wilayah barat, dan wilayah Alexandria. Segala permasalahan yang berkaitan dengan daerah dipercayakan kepada kepemimpinan setempat.

Dalam bidang kemiliteran terdapat tiga jabatan pokok, yaitu: Amir yang terdiri pejabat-pejabat tinggi militer dan pegawai khalifah, petugas keamanan, dan berbagai resimen. Pusat-pusat armada laut di bangun di Alexandria, Damika, Ascaton, dan beberapa pelabuhan Syiria. Masing-masing dikepalai seorang admiral tinggi. ${ }^{29}$

\section{Kondisi Sosial}

Mayoritas khalifah Fatimiyah bersikap moderat dan penuh perhatian kepada urusan agama nonmuslim. Selama masa ini pemeluk Kristen Mesir diperlakukan secara bijaksana, hanya khalifah al-Hakim yang agak keras kepada mereka. Orang-orang Kristen Kopti dan Armenia tidak pernah merasakan kemurahan dan keramahan melebihi sikap pemerintah muslim. Pada masa al-Aziz bahkan mereka lebih diuntungkan dari pada ummat Islam di

${ }^{28}$ K. Ali, Sejarah Islam (Tarikh Pramodern), h.339.

${ }^{29}$ Samsul Munir Amin, Sejarah Peradaban Islam., h.264. 
mana mereka ditunjuk menduduki jabatan-jabatan tinggi di istana. Demikian pula pada masa al-Mustansir dan seterusnya, mereka hidup penuh kedaimaian dan kemakmuran. Sebagaian besar jabatan keuangan dipegang oleh orang-orang Kopti. Pada khalifah generasi akhir, gereja-gereja Kristen pula semakin banyak yang diangkat sebagai pegawai pemerintah. Mayoritas khalifah Fatimiyah berpola hidup mewah dan santai. Al-Mustansir menurut informasi, menurut informasi mendirikan semacam Paviliun di istananya sebagai tempat memuaskan kegemaran berfoya-foya bersama penari rupawan. ${ }^{30}$

Nasir al-Khusraw, salah seorang pengembara Ismailiyah berkebangsaan Persia, yang mengunjungi Mesir antara tahun 1046-1049 M, meninggalkan catatan tentang kehidupan kota Kairo ibu kota Dinasti Fatimiyah. Pada saat itu ia mendapatkan kota Kairo sebagai makmur dan aman. Menurutnya toko-toko perhiasan dan pusat-pusat penukaran uang ditinggalkan oleh pemiliknya begitu saja tanpa kunci, rakyat menaruh keperayaan penuh kepada pemerintah, jalan-jalan raya diterangi beragam lampu. Para pedagang tokoh menjual barang dengan harga jual yang telah diputuskan dan jika seorang terbukti melanggar ketentuan harga jual dihukum dengan diarak di atas unta sepanjang jalan dengan diiringi bunyi-bunyian.

Nasir al-Khusraw menulis catatan bahwa ia menyaksikan khalifah pada sebuah festival tampak sangat mempesona dengan pakaian kebesarannya. Istana khalifah dihuni 30.000 orang, di antara mereka terdapat 12.000 orang pembantu dan 1.000 orang pengawal berkuda dan pengawal jalan kaki. Kota Kairo dihiasi dengan sejumlah Masjid, perguruan, rumah sakit, dan perkampungan khalifah. Tempat-tempat permandian umum yang cukup indah dapat dijumpai diberbagai penjuru kota. Pasar-pasar yang menuat 20.000 pertokon padat dengan produk-produk dunia. Nasir al-Khusraw sangat takjub atas kesejahteraan dan kemakmuran negeri ini, sehingga dengan takjub beliau berkata "saya tidak sanggup menaksir kesejahteraan dan kemakmuran negeri ini, dan saya belum pernah melihat kemakmuran sebagaimana yang terdapat di negeri ini".

Dinasti Fatimyah berhasil dalam mendirikan sebuah negara yang sangat luas dan peradaban yang berlainan semacam ini di dunia timur. Hal ini sangat menarik perhatian karena system administrasinya yangs angat baik sekali, aktivitas artistic, luasnya toleransi relijiusa, efisiensi angkatan perang dan angkatan laut, kejujuran pengadilan, dan terutama perlindungannya terhadap ilmu pengetahuanya terhadap ilmu pengetahua dan kebudayaan. ${ }^{31}$

${ }^{30}$ Samsul Munir Amin, Sejarah Peradaban Islam., h.265.

${ }^{31}$ Hasan Ibrahim Hasan, Sejarah dan Kebudayaan Islam., h.285. 


\section{Kemajuan Ilmu Pengetahuan dan Kesusastraan}

Sumbangan Dinasti Fatimiyah dalam kemajuan ilmu pengetahuan tidak sebesar sumbangan Abbasiyah di Bagdad dan Umayyah di Spanyol. Masa ini kurang produktif dalam menghasilkan karya tulis dan ulama besar kecuali dalam jumlah kecil, sekalipun banyak di antara khalifah dan para wazir menaruh perhatian dan penghormatan kepada para ilmuan dan pujangga. Ibnu Khilis merupakan salah seorang wazir yang sangat peduli terhadap pengajaran. Ia mendirkan sebuah lembaga pendidikan dan memberikan subsidi besar setiap bulan. Pada masa ibnu Khilis ini di dalam istana al-Aziz terdapat seorang Fisikiawan besar bernama Muhammad al-Tamim. Al-Kindi sejarawan dan topographer terbesar hidup di Fustat dan meninggal di tahun 961 M. Pakar terbesar pada awal Fatimiyah adalah Qazdi al-Nu'mān dan beberapa keturunannya yang meduduki jabatan Qādhi dan keagamaan tertinggi selama 50 tahun semenjak penaklukan Mesir sampai masa pemerintahan al-Hakim.

Isatana al-Hakim dihiasi dengan Ali bin Yunus pakar terbesar dalam bidang Astronomi dan ibnu Ali Hasan bin al-Haitami, seorang fisikiawan muslim terbesar dan juga ahli di bidang optic. ${ }^{32}$ Al-Hakim juga adalah orang yang besar minatnya dalam penelitian astronomi, olehnya itu beliau mendirikan lembaga observasi di bukit al-Makattam. Lembaga seperi ini juga didirikan di beberapa tempat lain. Para khalifah Fatimiyah pada umumnya juga mencintai berbagai seni termasuk seni arsitektu. Meraka memperindah ibu kota dan kota-kota lainnya dengan berbagai bangunan megah. Masjid agung al-Azhar dan masjid agung al-Hakim menandai kemajuan arsitektur zaman Fatimaiyah. Khalifah juga mendatangkan sejumlah arsitek Romawi untuk bantu menyelesaikan tiga buah gerbang raksasa di Kairodan benteng-benteng di wilayah perbatasan Bizantium. ${ }^{33}$

\section{Kemunduran dan Kehancuran Dinasti Fatimiyah}

Kekuasaan khalifah Fatimiyah di Mesir mulai mengalami kemunduran ketika bani saljuk bersama pasukannya datang ke Bagdad dan mengusir keluarga Buwaihi, bahkan akhirnya menangkap tokohnya yang bernama al-Bassasiri. Khalifah Fatimiyah tidak dapat memberikan pertolongan. Kemundurannya itu akhirnya membawa dinasti tersebut ke gerbang kehancurannya. Ada beberapa fktor yang menyebabkan kemunduran khilafah Fatimiyah tersebut, antara lain sebagai berikut:

32 K. Ali, Sejarah Islam (Tarikh Pramodern), h.341-342.

${ }^{33}$ Samsul Munir Amin, Sejarah Peradaban Islam., h.268. 
Pertama, Politik Fatimiyah yang keras terhadap masyarakat sunni Mesir untuk menganut dan mengakui ajaran Syi'ah. Pada awal kekuasaannya, penguasa Fatimiyah tampak bertindak arif, toleran, dan membebaskan penduduk menganut kepercayaanya. Hal ini tentu saja menimbulkan simpati masyarakat yang mayoritas Sunni. Namun, pada perjalanan berikutnya propaganda untuk menganut pemahaman Syi'ah kepada masyarakat mulai tampak menonjol. Pada masa al-Aziz misalnya, ia pernah membatalkan shalat tarawih di seluruh masjid pada tahun $372 \mathrm{H}$. sementara, pada masa al-Hakim, ia pernah menyuruh algojonya untuk membunuh siapa saja yang tidak mengakui keistimewaan Ali. ${ }^{34}$

Kedua, Pengawasan terhadap daerah-daerah kekuasaan Fatimiyah melemah. Dalam usaha ekspansi ke daerah-daerah, Fatimiyah telah banyak mengalami kesuksesan dan yang paling penting adalah penaklukan di Mesir, Syria dan Palestina. Walaupun Fatimiyah dapat menaklukkan daerah-daerah di atas, mereka mengalami kesulitan untuk mengadakan pengawasan secara seksama. Di daerah Palestina dan Syria, Fatimiyah tidak dapat menguasai secara penuh sehingga terjadi pemberontakan, seperti keluarga Tayyi dan pasukan Jarahid yang terus bergolak di Palestina dan kelompok Qaramithah yang tersus mengadakan perlawanan di Syria. Sebenarnya pada awalnya kahlifah Fatimiyah secara pribadi mengontrol semua kegiatan secara seksama, namun, di antara khalifah ada yang menyerah tugas pengawasan ini kepada amir. ${ }^{35}$

Ketiga, Peran khalifah yang tidak berfungsi secara utuh. Di antara khalifah Fatimiyah, ada yang diangkat pada saat usia mereka masih kanak-kanak. Al-Hakim diangkat pada saat usia 11 tahun, pemerintahannya ditandai dengan tindakan-tindakan kejam yang menakutkan. Ia membunuh beberapa orang wazirnya, menghancurkan beberapa kereja Kristen, termasuk di dalmnya kuburan suci umat Kristen. ${ }^{36}$ Bahkan al-Mustanshir diangkat pada usia 7 tahun. Kondisi ini tidak memungkinkan bagi khalifah untuk dapat menjalankan fungsinya sebagaimana mestinya. Untuk menjalankan pada masa al-Hakim, diangkatlah Barjuan sebagai guru yang mendampinginya. Karena kekuasaannya yang begitu besar Barjuan bertindak sebagai dictator. Kekuasaan pernah ada di tangannya. Gejala ini ditanggapi khalifah dengan berusaha keluar dari dominasi Barjuan hingga akhirnya dibunuh oleh al-Hakim. Pada masa al-Mustanshir banyak terjadi kekacauan dan kegoncangan

\footnotetext{
${ }^{34}$ W Montgomery Watt, Kejayaan Islam, terj. Hartono Hadikumoro (Yogyakarta: Tiara Wacana, 1990), h.253.

${ }^{35}$ Munthoha dkk, Pemikiran dan Peradaban Islam (Cet. I; Yogyakarta: UII Press, 1998), h.65.

${ }^{36}$ Khalkān, Abu al-Abbās Syamsuddin Ahmad bin Muhammad bin Abi Bakr. Wafayāt al-A'yān wa Anbāu Abnāl al-Zamān, h.5.
} 
menyusul beralihnya kekuasaan dari khalifah ke para menterinya. Demikian pula halnya dengan al-Faiz, pengganti al-Zafir. Kelemahan dalam menjalankan kekuasaan juga terjadi. Kekuasaan sepenuhnya dijalankan oleh wazirnya, Ibnu Ruzik. Hal ini menyebabkan terbunuhnya al-Faiz. ${ }^{37}$

Keempat, Konflik dalam tubuh Militer. Tentara yang mula-mula menaklukan Mesir terdiri dari orang-orang Barbar. Mereka menetap di garnizun-garnizun yang dibangun pada setiap daerah taklukan, tak terkecuali juga di Mesir. Hal berguna untuk menjaga kewibawaan khalifah Fatimiyah pada setiap daerah yang ditundukkan. Pada masa pemerintahan al-Aziz (365-386H/ 975-996M), orang-orang Turki dan para budak direktur menjadi tentara. Hal ini jelas menimbulkan konflik karena adanya friksi dalam tubuh militer ketika masing-masing mereka merasa kuat. Di samping itu, ada kekuatan ketiga yang menambah keruh suasana dalam tubuh militer yakni tentara dari budak hitam yang berasal dari Sudan yang tidak mau kalah dari para pendahulunya. Pertikaian ini pada akhirnya membawa pada kelemahan Fatimiyah. ${ }^{38}$

Kelima, Terjadi pemberontakan di Mesir dan sekitarnya. Ketika al-Mustansir berkuasa (1036-1094 M), terjadi perselisihan antara jenderal dan wazir. Khalifah alMustanshir tidak berhasil mengatasi kemelut ini sehingga mulailah kelihatan kelemahan kepemimpinannya. Kemudian muncul penolakan dari masyarakat Hijaz untuk terus berada di bawah kekuasaan Mesir. Sebagai alternative mengatasi kemelut ini, pada tahun $465 \mathrm{H} /$ $1073 \mathrm{M}$ ia mendatangkan Badr al-Jamali, seorang jenderal yang kuat dan berpengaruh dari suku Armenia dan menetapkannya sebagai wazir. ${ }^{39}$

Untuk menjaga kelanggengan kekuasaannya, wazir ini memerintahkan kepada orang kepercayaannya untuk membunuh para jenderal dan wazir yang berpengaruh. Alhasil, pada suatu malam, pejabat tersebut mengundang mereka untuk sebuah pesta yang makanan dan minumannya sudah dicampuri racun mematikan. Dalam pikirannya, dengan kekuatan militer yang ada di tangannya, maka segala hal dapat dengan efektif dikendalikan. ${ }^{40}$

Badr al-Jamali berusaha memperbaiki tatanan social masyarakat Mesir. Di tangannya Mesir memang dapat mencapai kemakmuran, namun di sisi lain, membawa pergolakan di tubuh militer. Ia digantikan oleh anaknya, kemudian oleh para penguasa militer, sekalipun mereka bukan dari golongan Syi'ah Ismailiyah. Tindakan ini pada

\footnotetext{
${ }^{37}$ W Montgomery Watt, Kejayaan Islam, h. 253

${ }^{38}$ Munthoha dkk, Pemikiran dan Peradaban Islam, h.66.

${ }^{39}$ Didin Saefuddin Buchori, Sejarah Politik Islam (Cet. I; Jakarta: PT. Pustaka Intermasa, 2009), h.156.

${ }^{40}$ Bernard Lewis, Encylopaedia Islam (Leiden: EJ Brills, 1979), h.194.
} 
akhirnya membawa kepada sentiment golongan lain dan mereka menunggu kesempatan yang tepat untuk menjatuhkan Badr al-Jamali beserta pendukung politinya.

Badr dan penggantinya dapat menyelamatkan Fatimiyah dan menunda kehancurannya selama satu abad. Ia ingin mengembalikan kekuasaan Fatimiyah serta merebut kembali daerah-daerah yang dulu pernah ditaklukan dan dikuasai Fatimiyah. Kenyataan yang didapati adalah kekalahan demi kekalahan, terutama di Syria dan Hijaz. Dengan demikian posisi Fatimiyah semakin melemah. Hal tersebut mengalami puncaknya setelah al-Mustanshir wafat. Al-Afdhal, pengganti Badr al-Jamali, mengangkat sebagai khalifah pengganti al-Mustanshir dengan gelar al-Musta'li. Sebenarnya khalifah telah memilih anaknya yang bernama Nizar untuk menjadi khalifah dan para pemuka Syi'ah pun telah menyepakatinya. ${ }^{41}$

Al-Afdhal tidak menyadari bahwa tindakannya ini telah memecah belah aliran Syi'ah hingga menimbulkan oposisi di Mesir, Persia, Irak, dan Asia Tengah. Ketika itu Hasan asSabah, sebagai pemimpin Syiah, menolak untuk mengakui khalifah baru tersebut dan tetap mengakui Nizar sehingga mereka juga disebut golongan Nizariyah. Hasan as-Sabah memiliki gerakan rahasia yang siap membunuh lawan-lawan politiknya atau penguasapenguasa yang menjadi musuhnya. Mereka menganggap Khalifah al-Musta'li di Mesir sebagai perampok kekuasaan yang sah dan harus dibunuh. ${ }^{42}$

Usaha membunuh al-Musta'li mencapai hasilnya pada tahun $1101 \mathrm{M}$. tidak hanya itu, mereka juga kemudian membunuh penggantinya al-Amir, pada tahun $525 \mathrm{H} / 1130 \mathrm{M}$. penggantinya adalah al-Hafiz. Namun, pengganti ini mendapatkan tantangan dari para pengikut Syi'ah Ismailiyah yang berada di Yaman karena mereka mengetahui bahwa alAmir memiliki anak yang masih bayi beranama Thayyib. Bayi inilah yang menurut mereka berhak atas kekhalifahan berikutnya karena dianggap sebagai imam maktum. Dengan demikian, mereka menolak Khalifah al-Hafiz dan pengganti-penggantinya. ${ }^{43}$

Keenam, Lemahnya perekonomian rakyat dan Negara. Sungai Nil sebagai sungai yang membawa kesuburan bagi tanah pertanian Mesir pada masa Khalifah al-Mustanshir pernah menyusut selama bertahun-tahun. Akibatnya, panen hancur, kelaparan meluas, dan wabah penyakit menyebar tanpa bisa dicegah. Kondisi perekonomian rakyat menjadi lumpuh, kestabilan politik menjadi rapuh, tindakan kriminalitas terjadi di mana-mana dan semua ini pada gilirannya membawa dampak pada kelemahan dan kehancuran negara. ${ }^{44}$

\footnotetext{
${ }^{41}$ Bernard Lewis, Encylopaedia Islam, h.194.

${ }^{42}$ Bernard Lewis, Encylopaedia Islam, h.194.

${ }^{43}$ Didin Saefuddin Buchori, Sejarah Politik Islam, h. 158.

${ }^{44}$ Didin Saefuddin Buchori, Sejarah Politik Islam, h. 158.
} 


\section{KESIMPULAN}

Dinasti Fatimiyah adalah salah satu dari Dinasti Syiah dalam sejarah Islam. Dinasti ini didirikan di Tunisia pada tahun 909 M oleh Ubaidillah al- Mahdi. Fathimiyyah adalah Dinasti syi'ah yang dipimpin oleh 14 Khalifah atau imam di Afrika dan Mesir tahun 9091171 M, selama lebih kurang 262 tahun. Kekhalifahan Fatimiyah lahir sebagai manifestasi dari idealisme orang-orang Syi' ah yang beranggapan bahwa yang berhak memangku jabatan imamah adalah keturuna dari Fatimah Binti Rasulullah. Kekhalifahan ini lahir diantara dua kekuatan politik, Abbasiyah di Baghdad, dan Umayah II di Cordova. Selama kurun waktu 262 tahun, Fatimiyah telah mencapai kemajuan yang pesat terutama pada masa Al-Muiz, Al-Aziz dan Al-hakim. Kemajuan-kemajuan itu mencakup berbagai bidang, yaitu: 1) Kemajuan dalam hubungan perdagangan dengan Dunia non Islam, termasuk India dan negeri-negeri Mediteramia yang Kristen. 2) Kemajuan di bidang seni, dapat dilihat pada sejumlah dekorasi dan arsitektur istana. 3) Dalam bidang pengetahuan dengan dibangunnya Universitas Al-Azhar. 4) Di bidang ekonomi, baik sektor pertanian, perdagangan maupun industri. 5) Di bidang keamanan.

Keruntuhan Dinasti Fatimiyah disebabkan oleh beberapa kelemahan yang ada pada masa pemerintahannya. Kelemahan-kelemahan itu antara lain: 1) Politik Fatimiyah yang keras terhadap masyarakat sunni Mesir untuk menganut dan mengakui ajaran Syi'ah. 2) Pengawasan terhadap daerah-daerah kekuasaan Fatimiyah melemah, 3) Lemahnya perekonomian rakyat dan negara, 4) Adanya resistensi dari orang-orang Sunni dan Nasrani di Mesir. 5) Terjadinya perebutan kekuasaan antara bangsa Barbar dan bangsa Turki terutama dalam bidang militer. 6) Datangnya serbuan dari tentara salib. Dan peran khilafah tidak berfungsi secara utuh. 


\section{DAFTAR PUSTAKA}

Ahmad, H. Zaenal Abidin. Sejarah Islam dan Ummatnya. Jakarta: Bulan bintang, 1979.

al-Hafni, Abdul Mun'im. Ensiklopedi Golongan, Kelompok, Aliran, Mazhab, Partai, dan Gerakan Islam Seluruh Dunia, (Cet. II; Jakarta: PT. Grafindo Khazanah Ilmu, 2009.

Amin, Samsul Munir. Sejarah Peradaban Islam. Jakarta: Amzah, 2010.

Asmuni, Yusran. Dirāsah Islāmiyah II Pengantar Studi Sejarah Kebudayaan Islam dan Pemikiran. Cet. III; Jakarta: Raja Grafindo Persada, 1998.

Azra, Azumardi. (Pimpinan Redaksi), Ensklopedi Islam. Jakrata; Ikhtiar Baru Van Hoove, 2005.

Bakri, Syamsul. Peta Sejarah Peradaban Islam. Cet. I; Yokyakarta: fajar Media Press, 2011.

Buchori, Didin Saefuddin. Sejarah Politik Islam. Cet. I; Jakarta: PT. Pustaka Intermasa, 2009.

H. Soekama Karya dan Tim Penyusun, Ensiklopedi Mini Sejarah dan Kebudayaan Islam . Cet. I; Jakarta: Logos Wacana Ilmu, 1996.

Hasan, Hasan Ibrahim. Sejarah dan Kebudayaan Islam. Yogyakarta: Kota Kembang, 1989.

Khalkān, Abu al-Abbās Syamsuddin Ahmad bin Muhammad bin Abi Bakr. Wafayāt alA'yān wa Anbāu Abnāi al-Zamān, (Cet. I; Beirut: Dār al-Șādir, 1994.

Lewis, Bernard. Encylopaedia Islam. Leiden: EJ Brills, 1979.

Munthoha dkk, Pemikiran dan Peradaban Islam. Cet. I; Yogyakarta: UII Press, 1998.

Phil K. Hitty, Capital Cities Of Arab Islam. Minneapolis : University Of Minnesota, 1973.

Philip K. Hitti, History Of The Arabs (Jakarta: Serambi Ilmu Semesta, 2010.

K. Ali, Sejarah Islam (Tarikh Pramodern). Jakarta: Srigunting, 1997.

Watt, W Montgomery. Kejayaan Islam, terj. Hartono Hadikumoro. Yogyakarta: Tiara Wacana, 1990.

William H. Frederick dan Soeri Soeroto, Pemahaman Sejarah Indonesia, sebelum dan sesudah revolusi. Jakarta; LP3ES, 1982. 